\title{
Enzyme Supplemented Neem Leaf Meal Based Diets: Effects on Carcass and Meat Quality of Broiler Chickens
}

\author{
Aanuoluwapo. A. Akintomide; Gbenga. E. Onibi
}

Department of Animal Production and Health, Federal University of Technology, Akure, Ondo State, Nigeria. *Corresponding Author: Akintomide, A.A. Email- aaakintomide@ futa.edu.ng

Received: 30 Dec 2021; Received in revised form: 11 Feb 2022; Accepted: 19 Feb 2022; Available online: 28 Feb 2022 (C)2022 The Author(s). Published by Infogain Publication. This is an open access article under the CC BY license (https://creativecommons.org/licenses/by/4.0/).

\begin{abstract}
The study investigated the influence of neem leaf meal (NLM) with or without enzyme supplementation on carcass and meat qualities of broiler chickens. Two hundred and eighty eight (288) broiler chickens were randomly allocated to diets in which NLM was included at 0, 1.5, 3 and 5\% with and without enzyme supplementation to form eight (8) dietary treatments. There were three (3) replicates per treatment and twelve (12) birds per replicate in a $4 \times 2$ factorial arrangement. At the end of the $8^{\text {th }}$ week, three chickens/ replicate were humanely slaughtered for assessment of carcass and organ characteristics and meat quality of the thigh, chest and drumstick muscles. The results showed that only the relative weights of back $(\mathrm{g} / \mathrm{kgLW})$ was significantly influenced $(P<0.05)$ by levels of $N L M$ inclusion. There was also significant $(P<0.05)$ increase in relative weights $(g / k g L W)$ of the liver and pancreas of the broilers with NLM inclusion. Cooking loss, thaw loss and palatability of meat from these chickens were not adversely affected by inclusion of NLM in the diets. Furthermore, the values obtained for moisture contents of the 3 muscles were within acceptable range. In conclusion, inclusion of NLM in broiler finishers' diets up to 5\% did not jeopardize the development of carcass and organs, and meat quality of the chickens. Additional effect of enzyme supplementation was not observed in this study.
\end{abstract}

Keywords-Polyzyme ${ }^{\circledR}$, Broiler finisher, Cooking loss, Thaw loss, Oxidative stability.

\section{INTRODUCTION}

The poultry industry has been a major supplier of affordable animal protein because chickens especially have a short generation interval, quick turnover, and fast growth rate (Allouche et al., 2015;Ubuaet al., 2019). However, highcost of conventional feedstuffs has been a major setback on the path of the industry in Nigeria (Sunmola, 2018). For instance, with the increase in production of maize and other feed stuffs, the price also keeps rising $(F A O, 2013)$ and in order to ensure fast and optimum growth of broiler chickens, provision of a well-balanced ration is necessary.

The search for alternative feed ingredients like agroindustrial waste (Fabunmi et al., 2019), leaf meal and other unconventional feed stuffs (Hien et al., 2017) became necessary so as to cushion the effect of high cost of feed ingredients vis-à-vis high cost of poultry feed. However these alternative feed ingredients come with considerable amount of fibre and antinutrients (Akintomide et al., 2021) but might be better utilized with the inclusion of exogenous enzymes (Razaet al., 2009) to the diet.Polyzyme ${ }^{\circledR}$, an exogenous enzyme,contains xylanase, phytase, cellulase, $\beta$ - glucanase, pectinases, $\alpha$ - amylase, protease, $\alpha$ - galactosidase, $\beta$ - galactosidase, lipase and mannanase, which are able to digest complex carbohydrates. Polyzyme®is used at the manufacturer's recommended dosage of $400 \mathrm{~g}$ per ton of mash feed (Sunmola et al., 2019).

Neem leaf contains a good amount of protein, minerals and vitamins although it is high in fibre which is characteristic of leaves (Ubua et al., 2019; Akintomide et al., 2021).Kumar et al.(2010) reported the relevance of neem leaf meal (NLM)to poultry due to itsanti-bacterial, anticoccidial, anti-oxidant and hepatoprotective properties. It 
could also serve as an antiprotozoal, antifungal and immune modulatory agent (Kale et al., 2003). Various inclusion levels has been suggested, Ubua et al. (2019) recommended the inclusion level of $2.5 \%$ NLM, Akintomide and Onibi (2018) reported that broilers were able to tolerate 5\% NLM and oral administration of aqueous infusions of neem leaf up to $0.3 \%$ in drinking water was reported by Egbeyale et al.(2021)but there is a dearth of information on the inclusion of NLM on broiler meat quality. This study was therefore designed to investigate the effect of NLM with or without Polyzyme® supplementation on carcass and organ characteristics, and meat quality of broiler chicken.

\section{MATERIALS AND METHODS}

Experimental Site: The feeding trial was carried out at the Poultry Unit of the Teaching and Research Farm, Federal University of Technology, Akure (FUTA), Ondo State, Nigeria. Geographically, it is located between latitude $7^{\circ} 5$ $\mathrm{N}$ and longitude $5^{\circ} 15 \mathrm{E}$ at an altitude of $370 \mathrm{~m}$ above sealevel (Oyinloye, 2013).

Experimental Treatments: The neem leaves used were harvested fresh from within Ondo State, dried and milled prior to dietary inclusion. Neem leaf meal was then included in broiler diets at $0,1.5,3.0$ and $5.0 \%$ with or without Polyzyme ${ }^{\circledR}$ supplementation to form eight (8) experimental treatments. Polyzyme ${ }^{\circledR}$ was used at the recommended rate of $400 \mathrm{~g} /$ ton feed.

Management Practices for Experimental Birds: The NENT (2018)ethical guidelines for the use of animals in research were adopted. The experiment was also approved after due presentations to the research protocol team of the Department of Animal Production and Health, FUTA. Two hundred and eighty eight (288) broiler chicks (Marshall Breed) were purchased from a reputable hatchery and were randomly allocated to the 8 dietary treatments. Each treatment was replicated thrice with 12 birds per replicate in a $4 \times 2$ factorial arrangement on a completely randomized design. Birds were raised under good hygienic conditions in deep litter throughout the experimental period which lasted for 8 weeks. Experimental diets and potable water was supplied ad libitum. Vaccines were administered as scheduled.

Carcass and Meat Quality Assessment:At the end of the $8^{\text {th }}$ week,three birds per replicate were randomly selected and humanely slaughtered for carcass and meat quality assessment.

Carcass and organ measurements: Live weight was taken at point of slaughter. At the end of the bleeding process the body weight was determined. Subsequently the chickens were defeathered after scalding in hot water, dressed, eviscerated, dissected into parts and weighed. The following weights were taken; live, eviscerated, thigh, drumstick, neck, head, shank, wing, chest and back. The internal organs; liver, kidney, lungs, heart, gizzard, proventriculus, spleen and pancreas were also separated and weighed.

Cooking loss: Meat samples of thigh, chest and drumstick were initially weighed (before cooking) and carefully put into well labeled polythene bags. These bags were then cooked in boiling water for 35 minutes after which they were removed, drained and allowed to cool to room temperature. Each cooked meat sample was then reweighed (final weight) and cooking loss obtained as: Cooking loss $(\%)=$ Initial weight of meat - Final weight of meat / Initial weight of meat x $100 / 1$.

Thaw loss: Frozen samples of the three muscle types were removed from the freezer after about four weeks, weighed (initial weight), put into well labeled nylon (perforated) and placed in the fridge for 24 hours to thaw. The samples were then removed from the nylons, mopped and reweighed (final weight). Thaw loss $(\%)=$ Initial weight of meat - Final weight of meat / Initial weight of meat x 100 / 1.

Moisture content: Moisture content of the three muscle types were determined. First, aluminum foil was weighed then meat sample was put into it and weighed again. The foil and content were placed into the oven at $70^{\circ} \mathrm{C}$ for 72 hours after which they were cooled and reweighed. Moisture content $(\%)=$ Loss in weight of sample $/$ Weight of sample before drying x $100 / 1$.

Palatability: The thigh muscle was used for palatability test after measurement of cooking loss. The samples were de - skinned, visible fat removed and cut into small pieces which were coded and evaluated by a 9 - member untrained student panel using a 9 point hedonic scale from extremely dislike (1) to extremely like (9).

\section{Statistical Analysis}

All data generated were subjected to one-way analysis of variance (ANOVA)and factorial analysis as appropriate. Where significant differences were found, means were compared using Tukey test of the Minitab Statistical Package Version 17.

\section{RESULTS}

\section{Carcass and Organ Characteristics}


Carcass characteristics of broiler chickens fed diets containing NLM supplemented with or without Polyzyme $®$ are presented in Table 1. Values for eviscerated weight, and relative weights of back, chest, wings, neck, head, shanks, thigh and drumstick were not significantly $(\mathrm{P}>0.05)$ different due to NLM inclusion.Live weight (LW) and back weight (BW) were however significantly $(\mathrm{P}<0.05)$ influenced by NLM inclusion. There was reduction in LW with increase in NLM inclusion. Values for both weights were highest for control $(1.72 \mathrm{~kg}$ $\mathrm{LW} ; 140.65 \mathrm{~g} / \mathrm{kg} \mathrm{LW}$ )and lowest for $5 \% \mathrm{NLM}(1.35 \mathrm{~kg} \mathrm{LW}$; $125.23 \mathrm{~g} / \mathrm{kg} \mathrm{LW})$. Live weight, eviscerated weight, back, chest, wings, neck, head, shanks, thigh, drumstick and abdominal fat were not significantly $(\mathrm{P}>0.05)$ influenced by Polyzyme® supplementation.

The results of the organ weights ( $\mathrm{g} / \mathrm{kg}$ live weight) of broiler finishers fed diets containing NLM with or without Polyzyme® supplementation are presented in Table 2 . The weights of liver, pancreas and proventriculus were significant $(\mathrm{P}<0.05)$ due to level of NLM fed to the broiler chickens. The relative weights of liver and pancreas followed same trend with 5\% NLM having the highest values and control having the lowest values. Broilers fed 5\% NLM also had the highest proventriculus weight. The relative weights of the liver, kidney, heart, lungs, gizzard, pancreas, proventriculus and spleen were not significantly $(\mathrm{P}>0.05)$ influenced by Polyzyme ${ }^{\circledR}$ supplementation.

\section{Meat quality}

Table 3 shows the cooking loss, thaw loss, moisture contentand palatability of meat from broiler finishers fed diets containing NLM with or without Polyzyme® supplementation. Percentage cooking loss for thigh, drumstick and chest were not significant $(\mathrm{P}>0.05)$ based on level of NLM and addition of Polyzyme ${ }^{\circledR}$. Cooking loss for the three muscles varied from 24.95-28.22\%, $18.93-21.27 \%$ and $25.42-26.69 \%$ respectively for NLM inclusion. Percentage thaw loss was also not significant $(\mathrm{P}>0.05)$ for the three muscles in relation to level of NLM and Polyzyme $®$ addition.

Percentage moisture content for thigh was significantly influenced $(\mathrm{P}<0.05)$ based on level of NLM, and that of drumstick based on Polyzyme ${ }^{\circledR}$ supplementation. Moisture content of the thigh muscle was highest for $1.5 \%$ NLM (73.98\%) and lowest for control $(68.90 \%)$ and value for drumstick was higher with Polyzyme ${ }^{\circledR}$ supplementation (74.43\%) than without (72.73\%). Palatability of the meat was not significantly $(\mathrm{P}>0.05)$ influenced in relation to level of NLM used and Polyzyme ${ }^{\circledR}$ supplementation.

\section{DISCUSSION}

Slaughtered chickens are not only sold as whole but also in smaller cuts. Hence, effect of alternative feedstuffs on these cuts is worth considering. Furthermore, meat from the chest, thigh and drumstick are the most expensive commercial cuts from a chicken (Adeyemi et al., 2008). Neem leaf meal (NLM) did not affect the carcass yield as seen in the non-significant differences recorded for eviscerated weight in this study. All parts except the back were not influenced by levels of NLM inclusion. Bonsuet al. (2012) also reported a non-significant difference in dressed weight of broilers fed up to $2.5 \%$ NLM in their diets. In addition, the results of this study agree with that of Ubuaet al. (2019) in which no significance was observed in the carcass characteristics of broilers fed NLM. So, it can be safely inferred that the inclusion of up to 5\% NLM promoted similar carcass development of the broilers as they utilized the NLM- based diets for muscle growth (Ubuaet al., 2019). Addition of Polyzyme® did not elicit any adverse effect on muscle development of the chickens. This is in line with the report of Sunmolaet al. (2019) in which no significant difference was observed in the dressed, thigh and breast weights of broiler chickens fed sweet orange peel meal withPolyzyme ${ }^{\circledR}$ supplementation. It is noteworthy that responses to feed enzymes are variable and they depend on enzymes, substrate and individual birds so, there could be physiological limitations to the use of enzymes (Ravindran, 2013).

An increase in the relative weights of liver and pancreas was observed with increased NLM inclusion. Birds on the 5\% NLM diets had the highest liver, pancreas and proventriculus weights. These three organs are highly involved in the digestion of feedstuffs. The proventriculus produces gastric juices and enzyme needed for digestion (PoultryHub, 2018), working closely with the gizzard. Svihus (2014) opined that the proventriculus and gizzard can be considered as one organ. The pancreas also produces the pancreatic juice to further aid digestion. In addition to bile production (PoultryHub, 2018), the liver helps to remove waste and toxins from the body system. So, increase in weights of these organs is suggestive of increased activities either due to the high fibre level of NLM or the phytochemicals it contains. According to Obunet al. (2013), there was no significant difference in liver and pancreas weights of broilers fed control and $5 \%$ NLM diets and a reduction $(\mathrm{P}<0.05)$ in gizzard weight was observed. Bonsuet al. (2012) also reported no significant difference in weights of liver and gizzard of broiler fed NLM up to $2.5 \%$.

It can be seen from the results that levels of NLM up to 5\% and Polyzyme ${ }^{\circledR}$ supplementation did not adversely affect the meat quality of these broiler chickens as depicted by 
the non-significance in cooking loss, thaw loss and palatability. Values for moisture content of thigh muscle though significant did not show any particular trend with inclusion of NLM. All values for moisture content were within the range of $66-75 \%$ described for meat by USDA (2011). According to Belle (1937), meat with cooking loss between $20-25 \%$ has excellent flavour and higher values of about $40-50 \%$ will leave the meat dry. High values of cooking loss will affect the eating quality of meat unfavourably (Mehmoodet al., 2019).Cooking loss values according to level of NLM in this study were between $18.93-28.22 \%$ and that of enzyme supplementation was between $20.15-26.95 \%$. Since these values were not up to $40 \%$, it could be safely inferred that the flavour and juiciness of meat from the broiler chickens were not adversely affected. The thaw loss across the 3 muscle types was less than $4 \%$ which in essence did not predispose the meat to high loss due to leaching of soluble protein and flavour. Contrary to Bonsuet al. (2012) that reported a slight bitter taste in meat of broilers fed up to $2.5 \% \mathrm{NLM}$, the palatability and general acceptability of meat in this study were not compromised.

\section{CONCLUSION}

It can be concluded that the inclusion of up to $5 \%$ neem leaf meal with or without Polyzme ${ }^{\circledR}$ supplementation did not jeopardize the carcass, organ and meat quality of broiler chickens. Moreover, there is the need for further research to justify the use of Polyzyme ${ }^{\circledR}$ in broiler diets with inclusion of neem leaf meal.

\section{REFERENCES}

[1] Adeyemi, O. A.,Eruvbetine, D., Oguntona, T., Dipeolu, M. and Agunbiade, J. A. (2008). Feeding broiler chicken with diets containing whole cassava root meal fermented with rumen filtrate. Archivos de Zootecnia, 57(218): 247-258.

[2] Akintomide, A. A., Osho, I. B. and Onibi, G. E. (2021). Growth performance and haematology of broiler chickens fed enzyme supplemented neem leaf meal -based diets. Nigerian Journal of Animal Production, 48(5):152-164.

[3] Akintomide, A.A. and Onibi, G.E. (2018). Growth performance, shank pigmentation and blood profile of broiler chickens fed neem leaf meal-based diets. International Journal of Environment, Agriculture and Biotechnology,3(2): 455-460.

[4] Allouche, L., Madani, T., Ait Hamouda, Z., Boucherit, M. R., Taleb, H., Samah, O., Rahmani, K. andTouabti, A. (2015). Effect ofaddition of exogenous enzymes inhypocaloric diet in broiler chicken on performance, biochemical parameters and meat characteristics.Biotechnology inAnimal Husbandry, 31(4): 551- 565 .
[5] Bonsu, F.R.K, Kagya-Agyemang, J.K., Kwenin, W.K.J. and Zanu, H. K. (2012). Medicinal response of broiler chickens to diets containing Neem (Azadirachta indica) leaf meal, haematology and meat sensory analysis.World Applied Science Journal. 19: 800-805.

[6] Egbeyale, L. T., Uza, O., Ayoola, A. A., Sobayo, R. A., Adeleye, O. O., Ayo-Ajasa, O. Y., $\quad$ Adewole, F. A., Ojetunji, O. C. and Oguntayo, I. (2021).Effect of neem (Azadirachta indica) leaves infusion on growth performance andcarcass quality of broiler chickens. Nigerian Society for Animal Production, 48(1): 142-151.

[7] Fabunmi, T. B., Arotupin, D. J.,Adegunloye, D. V., Orunmuyi, M.and Ododle, B. S. (2019). Effects ofkolanut husk formulated feed atgraded levels on growthperformance and health of Rossbroilers with or without enzyme inclusion. Acta ScientificAgriculture, 3(2): 105-113.

[8] FAO, (2013). Poultry feeding in tropical and sub-tropical countries.3rd edition. Food and Agricultural Organization, Rome, Italy, Pp. 529.

[9] Kale, B.P., Kothekar, M.A., Tayade, H.P., Jaju, J.B. and Mateenuddin, M. (2003). Effect of aqueous extract (Azadirachta indica) leaves on hepatoxicity inducedantitubercular drugs in rats. Indian Journal of Pharmacology, 35: 177-180

[10] Kumar, P. S., Mishra, D., Ghosh, G. and Panda, C. S. (2010). Biologicalaction and medicinal properties of various constituent of Azadirachta indica (Meliaceae)" an Overview.Annals of Biological Research, 1(3): 24-34.

[11] Lowe, B. (1937). Experimental cookery from the chemical and physical standpoint $2^{\text {nd }}$ edition.John Wiley \& Sons publishers.

[12] Mehmood, W, Qian, S., Zhang, C. and Li X. (2019). Biophysical properties and volumentric changes in breat meat of broilers and yellow-feathered chicken as affected by cooking process. International Journal of Food Properties, 22(1): 1935- 1951. DOI: 10.1080/10942912.2019.1696361

[13] NENT (2018). Ethical Guidelines for the Use of Animals in Research. National Committee for Research Ethics in Science and Technology (NENT), The Norwegian National Research Ethics Committees, Norway.

[14] Obun, C. O., Ukim, C. I., Olatunji, E. A. and Kehinde, A. S. (2013). Health and carcass implications of dietary inclusion of graded level of sun-cured neem (Azadirachta indica, A. juss) leaf meal for broilers. Greener Journal of Agricultural Sciences, 3(1): 48-54.

[15] Oyinloye, M. A. (2013). Monitoring spatialgrowth of educational institutionusing geographical informationsystem: a focus on FederalUniversity of Technology, Akure, Nigeria.American Journal ofHumanities and Social Sciences, 1(3): 163-173.

[16] PoultryHub (2018). Digestive system. www.poultryhub.org/physiology/body-systems/digestivesystem/. Accesed November, 2018.

[17] Ravindran, V. (2013). Feed enzymes: The science, practice, and metabolic realities. The Journal of Applied Poultry Research, 22(3): 628-636.

[18] Raza, S., Shraf, M.A., Pasha, T.N. and Latif, F. (2009). Effect of enzyme supplementation of broiler diets containing 
varying level of sunflower meal and crude fiber. Pakistan Journal of Botany, 41(5): 2543-2550.

[19] Sunmola, T. A. (2018). Dietary Effect(s) of Sweet Orange (Citrus sinensis) Peel Meal (SOPM) with and Without Polyzyme ${ }^{\circledR}$ Treatment on Broiler Chickens.M.Sc. thesis.Department of Animal Nutrition, Federal University of Agriculture, Makurdi, Benue State, Nigeria. 188 $\mathrm{pp}$

[20] Sunmola, T. A., Tuleun, C. D. and Oluremi, O.I.A. (2019). Use of sweet orange peel meal (SOPM) in broiler chicken diet with and without Polyzyme ${ }^{\circledR}$ Malaysian Society of Animal Production, 22(2): 35-44.
[21] Svihus, B. (2014). Function of the digestive system. The Journal of Applied Poultry Research, 23(2): 306-314.

[22] Ubua, J.A., Ozung, P.O. and Inagu, P.G. (2019). Dietary inclusion of neem (Azadirachta indica) leaf meal can influence growth performance and carcass characteristics of broiler chicken. Asian Journal of Biological Sciences. 12: 180-186.

[23] USDA (2011). United States Department of Agriculture.Water in meat and poultry. www.fsis.usda.gov. Accessed January, 2019 
Table 1: Carcass characteristics of broiler chickens fed diets containing neem leaf meal with or without Polyzyme ${ }^{\circledR}$ supplementation

\begin{tabular}{|c|c|c|c|c|c|c|c|c|c|c|c|c|}
\hline \multirow[t]{2}{*}{ Diets } & \multirow{2}{*}{$\begin{array}{c}\text { Level of } \\
\text { inclusion } \\
(\%)\end{array}$} & \multirow{2}{*}{$\begin{array}{l}\text { Polyzyme® } \\
\text { supplementat } \\
\text { ion }\end{array}$} & \multirow{2}{*}{$\begin{array}{l}\text { Live } \\
\text { weight } \\
\text { (kg) }\end{array}$} & \multirow{2}{*}{$\begin{array}{l}\text { Eviscerated } \\
\text { weight }(\%)\end{array}$} & \multicolumn{2}{|l|}{$\leftarrow$} & \multirow[b]{2}{*}{ Wings } & \multicolumn{2}{|c|}{ g/kg live weight } & \multirow{2}{*}{ Shank } & \multirow[b]{2}{*}{ Thigh } & \multirow[b]{2}{*}{ Drumstick } \\
\hline & & & & & Back & Chest & & Neck & Head & & & \\
\hline \multirow[t]{2}{*}{ Control } & 0 & With & $1.77^{\mathrm{a}}$ & 74.97 & 139.94 & 207.14 & 78.05 & 37.41 & 24.95 & 43.86 & 105.08 & 101.97 \\
\hline & & Without & $1.68^{\mathrm{ab}}$ & 74.50 & 141.28 & 198.39 & 79.26 & 40.01 & 25.49 & 46.17 & 101.36 & 101.14 \\
\hline \multirow[t]{6}{*}{ Neem leaf meal based } & 1.5 & With & $1.54^{\mathrm{ab}}$ & 77.64 & 131.66 & 202.76 & 79.48 & 39.32 & 25.32 & 44.22 & 96.34 & 99.29 \\
\hline & & Without & $1.52^{\mathrm{ab}}$ & 76.10 & 132.83 & 199.10 & 79.37 & 38.89 & 25.75 & 44.30 & 100.18 & 102.97 \\
\hline & 3 & With & $1.46^{\mathrm{ab}}$ & 74.44 & 133.33 & 195.78 & 79.27 & 37.06 & 25.81 & 45.02 & 196.80 & 104.14 \\
\hline & & Without & $1.47^{\mathrm{ab}}$ & 72.86 & 137.49 & 185.45 & 78.19 & 40.56 & 47.60 & 42.48 & 99.79 & 97.16 \\
\hline & 5 & With & $1.29^{\mathrm{b}}$ & 67.59 & 122.39 & 171.00 & 77.26 & 35.20 & 26.57 & 42.95 & 93.47 & 103.98 \\
\hline & & Without & $1.41^{\mathrm{ab}}$ & 72.93 & 128.07 & 187.20 & 79.16 & 38.43 & 29.00 & 44.83 & 94.10 & 100.41 \\
\hline \multicolumn{3}{|l|}{ Pooled standard deviation } & 0.30 & 8.04 & 0.30 & 29.25 & 7.49 & 8.22 & 26.22 & 6.41 & 100.45 & 14.13 \\
\hline \multicolumn{3}{|c|}{ Level of neem leaf meal (NLM) } & $*$ & NS & $*$ & NS & NS & NS & NS & NS & NS & NS \\
\hline \multicolumn{3}{|l|}{ Polyzme supplementation } & NS & NS & NS & NS & NS & NS & NS & NS & NS & NS \\
\hline \multicolumn{3}{|c|}{ Interaction between NLM and Polyzme } & NS & NS & NS & NS & NS & NS & NS & NS & NS & NS \\
\hline \multicolumn{13}{|l|}{ Mean separation } \\
\hline \multirow[t]{4}{*}{ Level of neem leaf meal } & & 0 & $1.72^{\mathrm{c}}$ & 74.72 & $140.65^{\mathrm{c}}$ & 202.51 & 78.69 & 38.79 & 25.24 & 45.08 & 103.11 & 101.53 \\
\hline & & 1.5 & $1.53^{\mathrm{cd}}$ & 76.82 & $132.28^{\mathrm{cd}}$ & 200.83 & 79.42 & 39.09 & 25.55 & 44.26 & 98.37 & 101.24 \\
\hline & & 3 & $1.46^{\mathrm{d}}$ & 73.65 & $135.41^{\mathrm{cd}}$ & 190.62 & 78.73 & 38.81 & 36.70 & 43.75 & 148.30 & 100.65 \\
\hline & & 5 & $1.35^{\mathrm{d}}$ & 70.26 & $125.23^{\mathrm{d}}$ & 179.12 & 78.21 & 36.81 & 27.78 & 43.89 & 93.78 & 102.20 \\
\hline \multicolumn{3}{|l|}{ Pooled standard deviation } & 0.29 & 0.29 & 16.01 & 28.89 & 7.29 & 8.09 & 26.05 & 6.29 & 100.61 & 13.88 \\
\hline \multirow{2}{*}{\multicolumn{2}{|c|}{ Polyzme supplementation }} & With & 1.50 & 73.50 & 131.60 & 193.54 & 78.50 & 37.18 & 25.69 & 44.01 & 124.20 & 102.45 \\
\hline & & Without & 1.52 & 74.10 & 134.91 & 192.55 & 78.99 & 39.47 & 31.97 & 44.44 & 98.86 & 100.42 \\
\hline \multicolumn{3}{|l|}{ Pooled standard deviation } & 0.32 & 8.18 & 16.68 & 30.00 & 7.19 & 7.94 & 25.91 & 6.22 & 100.80 & 13.65 \\
\hline
\end{tabular}

NS = Not significant $(\mathrm{P}>0.05), \quad *=\mathrm{P}<0.05$

${ }^{\mathrm{cd}}$ Means with different superscripts (cd) are significant based on factorial analysis for effect of level of neem leaf meal $(\mathrm{P}<0.05)$ 
Table 2: Organ weights ( $\mathrm{g} / \mathrm{kg}$ live weight) of broiler chickens fed diets containing neem leaf meal with or withoutPolyzyme ${ }^{\circledR}$ supplementation

\begin{tabular}{|c|c|c|c|c|c|c|c|c|c|c|}
\hline Diets & $\begin{array}{c}\text { Level of inclusion } \\
(\%)\end{array}$ & $\begin{array}{l}\text { Polyzyme }{ }^{\circledR} \\
\text { supplementati } \\
\text { on }\end{array}$ & Liver & Kidney & Heart & Spleen & Lungs & Gizzard & $\begin{array}{l}\text { Pancre } \\
\text { as }\end{array}$ & $\begin{array}{l}\text { Proventric } \\
\text { ulus }\end{array}$ \\
\hline \multirow[t]{2}{*}{ Control } & 0 & With & 20.04 & 5.99 & 3.91 & 1.11 & 6.01 & 19.39 & 2.22 & 6.21 \\
\hline & & Without & 21.15 & 5.81 & 4.12 & 1.16 & 6.40 & 19.80 & 2.16 & 5.71 \\
\hline \multirow[t]{6}{*}{ Neem leaf meal based } & 1.5 & With & 23.08 & 5.98 & 4.09 & 1.30 & 5.94 & 21.67 & 2.68 & 4.87 \\
\hline & & Without & 23.34 & 5.92 & 4.20 & 1.27 & 5.19 & 20.61 & 2.49 & 5.77 \\
\hline & 3 & With & 22.56 & 5.87 & 4.28 & 1.24 & 6.15 & 21.37 & 2.57 & 5.92 \\
\hline & & Without & 23.20 & 5.90 & 4.30 & 1.21 & 5.84 & 20.97 & 2.39 & 6.66 \\
\hline & 5 & With & 23.68 & 6.40 & 4.28 & 1.21 & 6.07 & 19.56 & 3.01 & 6.55 \\
\hline & & Without & 27.38 & 5.81 & 4.24 & 1.17 & 5.26 & 21.76 & 2.80 & 7.35 \\
\hline \multicolumn{3}{|l|}{ Pooled standard deviation } & 4.60 & 1.61 & 0.75 & 0.36 & 1.27 & 3.63 & 0.74 & 1.61 \\
\hline \multicolumn{3}{|l|}{ Level of neem leaf meal (NLM) } & $*$ & NS & NS & NS & NS & NS & $*$ & $*$ \\
\hline \multicolumn{3}{|l|}{ Polyzme supplementation } & NS & NS & NS & NS & NS & NS & NS & NS \\
\hline \multicolumn{3}{|c|}{ Interaction between NLM and Polyzme } & NS & NS & NS & NS & NS & NS & NS & NS \\
\hline \multicolumn{11}{|l|}{ Mean separation } \\
\hline \multirow[t]{4}{*}{ Level of neem leaf meal } & 0 & & $20.63^{\mathrm{b}}$ & 5.89 & 4.02 & 1.14 & 6.22 & 19.61 & $2.19^{\mathrm{b}}$ & $5.94^{\mathrm{ab}}$ \\
\hline & 1.5 & & $23.22^{\mathrm{ab}}$ & 5.95 & 4.14 & 1.29 & 5.54 & 21.11 & $2.58^{\mathrm{ab}}$ & $5.35^{\mathrm{b}}$ \\
\hline & 3 & & $22.88^{\mathrm{ab}}$ & 5.88 & 4.29 & 1.22 & 6.00 & 21.17 & $2.47^{\mathrm{ab}}$ & $6.29^{\mathrm{ab}}$ \\
\hline & 5 & & $25.53^{\mathrm{a}}$ & 6.11 & 4.26 & 1.19 & 5.67 & 20.66 & $2.90^{\mathrm{a}}$ & $6.95^{\mathrm{a}}$ \\
\hline \multicolumn{3}{|l|}{ Pooled standard deviation } & 4.57 & 1.57 & 0.72 & 0.35 & 1.27 & 3.58 & 0.72 & 1.61 \\
\hline \multirow[t]{2}{*}{ Polyzme supplementation } & & With & 22.39 & 6.06 & 4.15 & 1.22 & 6.05 & 20.50 & 2.63 & 5.91 \\
\hline & Without & & 23.77 & 5.86 & 4.22 & 1.20 & 5.68 & 20.79 & 2.46 & 6.37 \\
\hline \multicolumn{3}{|l|}{ Pooled standard deviation } & 4.78 & 1.55 & 0.72 & 0.35 & 1.26 & 3.58 & 0.75 & 1.67 \\
\hline
\end{tabular}


NS $=$ Not significant $(\mathrm{P}>0.05) \quad *=\mathrm{P}<0.05$

${ }^{a b}$ Means with different superscripts $(\mathrm{ab})$ are significant based on factorial analysis for effect of level of neem leaf meal $(\mathrm{P}<0.05)$

Table 3: Meat quality of broiler chickens fed diets containing neem leaf meal with or without Polyzyme ${ }^{\circledR}$ supplementation

\begin{tabular}{|c|c|c|c|c|c|c|c|c|c|c|c|c|}
\hline \multirow[t]{2}{*}{ Diets } & \multirow{2}{*}{$\begin{array}{c}\text { Level of } \\
\text { inclusion } \\
(\%)\end{array}$} & \multirow{2}{*}{$\begin{array}{l}\text { Polyzyme }{ }^{\circledR} \\
\text { supplementa } \\
\text { tion }\end{array}$} & \multicolumn{3}{|c|}{ Cooking loss (\%) } & \multicolumn{3}{|c|}{ Thaw loss (\%) } & \multicolumn{3}{|c|}{ Moisture content (\%) } & \multirow[t]{2}{*}{ Palatability } \\
\hline & & & Thigh & $\begin{array}{c}\text { Drum- } \\
\text { stick }\end{array}$ & Chest & Thigh & $\begin{array}{l}\text { Drum- } \\
\text { stick }\end{array}$ & Chest & Thigh & $\begin{array}{l}\text { Drum- } \\
\text { stick }\end{array}$ & Chest & \\
\hline \multirow[t]{2}{*}{ Control } & 0 & With & 24.06 & 19.32 & 24.12 & 0.47 & 3.10 & 0.53 & $67.91^{\mathrm{bc}}$ & 75.48 & 72.81 & 6.30 \\
\hline & & Without & 26.31 & 18.54 & 29.25 & 0.77 & 0.77 & 1.07 & $69.89^{\mathrm{abc}}$ & 72.92 & 71.04 & 7.00 \\
\hline \multirow{6}{*}{$\begin{array}{l}\text { Neem leaf } \\
\text { meal } \\
\text { based }\end{array}$} & 1.5 & With & 25.43 & 20.16 & 25.95 & 0.67 & 0.40 & 0.54 & $72.57^{\mathrm{ab}}$ & 75.07 & 73.83 & 6.40 \\
\hline & & Without & 24.46 & 21.76 & 24.88 & 0.23 & 0.27 & 1.76 & $75.39^{\mathrm{a}}$ & 74.22 & 74.59 & 7.50 \\
\hline & 3 & With & 27.86 & 19.48 & 27.90 & 0.25 & 1.25 & 0.16 & $73.18^{\mathrm{ab}}$ & 74.61 & 73.83 & 6.60 \\
\hline & & Without & 27.83 & 20.56 & 24.56 & 0.24 & 1.34 & 0.61 & $65.83^{c}$ & 71.61 & 70.25 & 6.50 \\
\hline & 5 & With & 30.43 & 21.65 & 28.44 & 0.66 & 2.53 & 0.76 & $73.35^{\mathrm{ab}}$ & 72.56 & 72.98 & 7.50 \\
\hline & & Without & 26.00 & 20.89 & 22.76 & 0.72 & 2.61 & 0.59 & $73.54^{\mathrm{a}}$ & 72.15 & 72.66 & 6.40 \\
\hline \multicolumn{3}{|c|}{$\begin{array}{l}\text { Pooled standard } \\
\text { deviation }\end{array}$} & 2.90 & 3.37 & 3.41 & 0.45 & 2.52 & 0.74 & 1.95 & 1.77 & 1.79 & 1.47 \\
\hline \multicolumn{3}{|c|}{ Level of neem leaf meal (NLM) } & NS & NS & NS & NS & NS & NS & $*$ & NS & NS & NS \\
\hline \multicolumn{3}{|c|}{ Polyzme supplementation } & NS & NS & NS & NS & NS & NS & NS & $*$ & NS & NS \\
\hline \multicolumn{3}{|c|}{ Interaction between NLM and Polyzme } & NS & NS & NS & NS & NS & NS & NS & NS & NS & NS \\
\hline
\end{tabular}

\section{Mean separation \\ Level of neem leaf meal}

$\begin{array}{lllllllllll}0 & 25.19 & 18.93 & 26.69 & 0.62 & 1.93 & 0.80 & 68.90^{\mathrm{e}} & 74.20 & 71.93 & 6.65 \\ 1.5 & 24.95 & 20.96 & 25.42 & 0.45 & 0.33 & 1.15 & 73.98^{\mathrm{d}} & 74.64 & 74.21 & 6.95 \\ 3 & 27.85 & 20.02 & 26.23 & 0.24 & 1.30 & 0.39 & 69.51^{\text {de }} & 73.11 & 72.04 & 6.55\end{array}$

ISSN: 2456-1878 (Int. J. Environ. Agric. Biotech.)

https://dx.doi.org/10.22161/ijeab.71.27 


\begin{tabular}{|c|c|c|c|c|c|c|c|c|c|c|}
\hline 5 & 28.22 & 21.27 & 25.60 & 0.69 & 2.57 & 0.68 & $73.44^{\mathrm{de}}$ & 72.36 & 72.82 & 6.95 \\
\hline Pooled standard deviation & 2.94 & 3.08 & 3.82 & 0.43 & 2.57 & 0.77 & 2.83 & 1.93 & 1.96 & 1.49 \\
\hline \multicolumn{11}{|l|}{ Polyzme supplementation } \\
\hline With & 26.95 & 20.15 & 26.60 & 0.51 & 1.82 & 0.50 & 71.75 & $74.43^{\mathrm{f}}$ & 73.37 & 6.70 \\
\hline Without & 26.15 & 20.44 & 25.36 & 0.49 & 1.25 & 1.01 & 71.17 & $72.73^{\mathrm{g}}$ & 72.13 & 6.85 \\
\hline Pooled standard deviation & 3.18 & 3.08 & 3.62 & 0.45 & 2.38 & 0.74 & 3.58 & 1.86 & 1.99 & 1.48 \\
\hline
\end{tabular}

NS $=$ Not significant $(\mathrm{P}>0.05) \quad *=\mathrm{P}<0.05$

${ }^{\mathrm{ab}}$ Means with different superscripts $(\mathrm{ab})$ are significant based on factorial analysis for effect of level of neem leaf meal $(\mathrm{P}<0.05)$

${ }^{\mathrm{fg}}$ Means with different superscripts (fg) are significant based on factorial analysis for effect of polyzyme supplementation $(\mathrm{P}<0.05)$ 